\title{
Occupational Risks and Hepatitis B Vaccination Status of Dental Auxiliaries in Nigeria
}

\author{
C.C. Azodo ${ }^{a}$ O. Ehigiator ${ }^{b}$ M.A. Ojo ${ }^{b}$
}

Departments of a Periodontics and ${ }^{b}$ Oral Medicine and Pathology, University of Benin Teaching Hospital, Benin City, Nigeria

\section{Key Words}

Occupational risk $\cdot$ Hepatitis B - Vaccination - Dental auxiliaries

\begin{abstract}
Objective: To assess the occupational exposure to needlestick and sharps injuries and hepatitis B vaccination status among dental auxiliaries. Subjects and Methods: A descriptive cross-sectional survey of 83 dental auxiliaries was conducted that included 12 technologists, 11 therapists, 53 nurses/surgical assistants, and 7 record officers. The survey included demography, history of needlestick and sharps injury, hepatitis B vaccination, knowledge and attitude towards HIV-infected patients, and the dental auxiliaries' information needs on HIV-related issues. Results: Of the 83 dental auxiliaries, 34 (41\%) had experienced needlestick and sharps injury in the last 12 months. At the time of the study, only 43 (51.8\%) had been immunized against hepatitis B. 62 (74.7\%) of the respondents thought that it was easier to contract HIV than hepatitis B through needlestick in a dental clinic. 21 (25.3\%) would not assist dentists treating HIV-positive patients. However, 76 (91.6\%), a majority, agreed that they needed more information on HIV-related issues, with 59 (71.1\%) specifying a single area of need and 17 (20.5\%) more than one area of need. The single areas of need specified in
\end{abstract}

descending order were infection control ( $n=22,26.5 \%)$, HIV counseling ( $n=12,14.5 \%)$, oral manifestations of HIV/AIDS ( $n=11,13.3 \%)$, postexposure prophylaxis $(n=9,10.8 \%)$, and antiretroviral therapy ( $n=5,6.0 \%)$. Conclusion: The data from this survey underscore the urgent need for educational interventions to encourage safe work practices. Hepatitis $B$ vaccination, HIV-related knowledge and proper postexposure prophylaxis are needed to prevent occupational transmission of blood-borne viruses.

Copyright $\odot 2010$ S. Karger AG, Base

\section{Introduction}

Needlestick and sharps injuries are among the most prevalent risks for accidents in hospitals worldwide [1]. Workers at risk include dental healthcare workers, nurses, operating assistants, phlebotomists, porters, cleaners, laundry and refuse workers [2]. The World Health Organization estimates that approximately 3 million cases of needlestick injuries occur among healthcare workers each year, with $90 \%$ of these occurring in developing countries [3]. Needlestick and sharps injuries pose a potential occupational risk to dental healthcare workers, particularly for transmission of blood-borne viruses, such as hepatitis B virus (HBV), hepatitis C virus and

\section{KARGER}

Fax +41613061234

E-Mail karger@karger.ch

www.karger.com
(C) 2010 S. Karger AG, Basel

$1011-7571 / 10 / 0195-0364 \$ 26.00 / 0$

Accessible online at:

www.karger.com/mpp
Dr. Clement Chinedu Azodo

Department of Periodontics, University of Benin Teaching Hospital

New Dental Complex, PMB 1111 Ugbowo

300001 Benin City, Edo State (Nigeria)

E-Mail clementazodo@yahoo.com 
HIV. The first case of occupationally acquired HBV and HIV infection in a healthcare worker following needlestick exposure to contaminated blood was reported in 1949 and 1984, respectively [4].

The prominence of the topic of HIV infection in media reports for the general public and in journals for healthcare professionals has focused attention on the occupational risk of exposure to blood-borne pathogens, with reports of the occupation-related route of blood-borne pathogen transmission in dentistry through percutaneous injury [5]. The risk of HIV transmission without prophylaxis is $0.3 \%$ from percutaneous injury [6]. For unvaccinated healthcare workers, the risk from single needlestick or cut exposure to HBV-infected blood ranges from 6 to $30 \%$, depending on the hepatitis B antigen status of the source individual [7].

Nigerian-based studies on occupational exposure have been conducted on all healthcare workers [2], dental students [8,9], and medical students [10], but none has been done exclusively on dental auxiliaries. The objective of this study was to assess the occupational exposure to needlestick and sharps injuries, and hepatitis B vaccination status among dental auxiliaries.

\section{Subjects and Methods}

This research was conducted as a descriptive cross-sectional survey of dental technologists, therapists, nurses and record officers working in Onitsha, Benin City, Lagos, Ibadan and Ile-Ife, Nigeria. A total of 83 dental auxiliaries were surveyed, mean age $34 \pm 10.6$ years. Age range was $18-60$ years; 63 were females and 20 males. 53 were assistants/nurses, 11 therapists, 12 technologists and 7 record officers.

A self-administered questionnaire was used to collect information on demography, needlestick and sharps injury, hepatitis B vaccination, knowledge and attitude towards HIV patients, and their needs on HIV-related issues.

Ethical approval of this survey was obtained from University of Benin Teaching Hospital Ethics Committee. Informed consent was obtained from individual participants before the commencement of the survey.

Statistical Package for Social Sciences (SPSS version 15.0) was used for data analysis; $\chi^{2}$ was used for test of significance at $\mathrm{p}$ value $\leq 0.05$

\section{Results}

Of the 83 participants, 34 (41\%) had experienced needlestick and sharps injury in the last 12 months. At the time of the study, only $43(51.8 \%)$ participants had been vaccinated for hepatitis B. $62(74.7 \%)$ of the partici- pants agreed that it was easier to contract HIV than hepatitis B through needlestick in the dental clinic. A quarter $(21,25.3 \%)$ of the participants would not render support and assistance to the dentist treating HIV-positive patients.

A majority $(76,91.6 \%)$ agreed that they need more information on HIV-related issues, with 59 (71.1\%) specifying a single area of need and 17 (20.5\%) more than one area of need. The single areas of need in descending order were infection control: $\mathrm{n}=22$ (26.5\%); HIV counseling: $\mathrm{n}=12$ (14.5\%); oral manifestations of HIV/AIDS: $\mathrm{n}=11$ (13.3\%); postexposure prophylaxis: $\mathrm{n}=9(10.8 \%)$, and antiretroviral therapy: $\mathrm{n}=5$ (6.0\%).

\section{Discussion}

HBV and HIV infection have long been considered to be work hazards for healthcare workers [11]. Percutaneous injuries occur predominantly during extraoral procedures such as laboratory work, operatory clean-up, and instrument preparation for sterilization, which are functions of dental auxiliaries $[5,12]$.

A study conducted in Nigeria a decade and a half ago showed that dental auxiliaries were among the health workers most affected by sharp instrument injuries [2]. Studies on dental healthcare workers revealed that percutaneous injuries were higher among dental auxiliaries, who were more affected than dentists $[13,14]$. In our study, $41 \%$ of the participants had experienced needlestick and sharps injury in the last 12 months, which was high and similar to the findings of studies on dental hygienists and registered dental assistants in Minnesota, USA and South Africa [15-17].

Protective measures against occupational exposure to HBV must be made in order to prevent infection to dental care workers, the most important of which is hepatitis B vaccination. It has been shown that dental care workers who have received hepatitis B vaccine and consequently developed immunity to the virus are at virtually no risk for the infection [17]. At the time of our study, only $51.8 \%$ of the participants had been vaccinated for hepatitis B, which was lower than the $63 \%$ reported among dental health care workers in Taegu, South Korea [18], but higher than the $46 \%$ reported among dental professionals in Vancouver, British Columbia [19] and Japan [20], respectively. It was significantly higher than the 14 and $24.4 \%$ reported in commercial dental laboratories in Jordan [21] and by Nigerian dental technologists [22], respectively. The number of unimmunized participants in this study 
was $48.2 \%$, which was similar to the $48.8 \%$ documented among Nigerian dentists [23]. For an unvaccinated person, the risk from a single needlestick or a cut exposure to HBV-infected blood ranges from 6 to 30\% [7], and the average risk for HIV infection after a needlestick or cut exposure to HIV-infected blood is $0.3 \%$ [6]. Yet in our study, about three quarters (74.7\%) of the participants agreed that it was easier to contract HIV than HBV through needlestick in a dental clinic, indicating inadequate knowledge of contracting either HBV or HIV among our study population, as reported previously [22].

In previous studies $[15,24]$, dental auxiliaries had indicated unwillingness to render support or assistance to dentists treating HIV/AIDS-infected patients; this was confirmed in our study. Such unwillingness could be due to insufficient knowledge on safe and effective care for patients with hepatitis B, hepatitis B carriers or individu- als affected with HIV. Such unwillingness could constitute a hindrance to oral care access to HIV-infected persons. Fortunately, in our study, a majority $(91.6 \%)$ agreed that they needed more information on HIV-related issues, with 59 (71.1\%) specifying a single area of need and $17(20.5 \%)$ more than one area of need, similar to a study in South Africa [25].

\section{Conclusion}

The data from this survey highlight the urgent need for educational interventions to encourage safe work practices. Hepatitis B vaccination, HIV-related knowledge and proper postexposure prophylaxis are needed to prevent occupational transmission of blood-borne viruses.

\section{References}

1 Prüss-Üstün A, Rapiti E, Hutin Y: Sharps Injuries: Global Burden of Disease from Sharps Injuries to Health-Care Workers. WHO Environmental Burden of Disease Series. Geneva, World Health Organization, 2003, No 3.

2 Adegboye AA, Moss GB, Soyinka F, Kreiss JK: The epidemiology of needlestick and sharp instrument accidents in a Nigerian hospital. Infect Control Hosp Epidemiol 1994;15:27-31.

3 World Health Organization: Health Care Worker Safety Aide-Mémoire. Geneva, WHO, 2003.

4 Anonymous: Needlestick transmission of HTLV-III from a patient infected in Africa. Lancet 1984;ii:1376-1377.

5 Cleveland JL, Lockwood SA, Gooch BF, Mendelson MH, Chamberland ME, Valauri DV, Roistacher SL, Solomon JM, Marianos DW: Percutaneous injuries in dentistry: an observational study. J Am Dent Assoc 1995; 126:745-751.

6 Ippolito G, Puro V, Heptonstall J, Jagger J, De Carli G, Petrosillo N: Occupational human immunodeficiency virus infection in health care workers: worldwide cases through September 1997. Clin Infect Dis 1999;28:365383.

7 Centers for Disease Control and Prevention: Immunization of health-care workers: recommendations of the Advisory Committee on Immunization Practices (ACIP) and the Hospital Infection Control Practices Advisory Committee (HICPAC). MMWR Recomm Rep 1997;46(RR-18):1-42.

8 Utomi IL: Occupational exposures and infection control among students in Nigerian dental schools. Odontostomatol Trop 2006; 29:35-40.

$\checkmark$ Sofola OO, Folayan MO, Denloye OO, Okeigbemen SA: Occupational exposure to bloodborne pathogens and management of exposure incidents in Nigerian dental schools. J Dent Educ 2007;71:832-837.

10 Okeke EN, Ladep NG, Agaba EI, Malu AO: Hepatitis $B$ vaccination status and needle stick injuries among medical students in a Nigerian university. Niger J Med 2008; 17: 330-332.

11 Fleming AF: Transmission of HIV and HBV in the health-care setting. Curr AIDS Lit 1991;8:289-291.

12 Gooch BF, Cardo DM, Marcus R, McKibben PS, Cleveland JL, Srivastava PU, Culver DH, Bell DM: Percutaneous exposures to HIVinfected blood among dental workers enrolled in the CDC Needlestick Study. J Am Dent Assoc 1995;126:1237-1242.

13 Shah SM, Merchant AT, Dosman JA: Percutaneous injuries among dental professionals in Washington State. BMC Public Health 2006;6:269.

14 Cleveland JL, Barker LK, Cuny EJ, Panlilio AL: National Surveillance System for Health Care Workers Group: preventing percutaneous injuries among dental health care personnel. J Am Dent Assoc 2007;138:169-178; quiz 247-248.

15 Hastreiter RJ, Roesch MH, Heckert KA, Danila RN: Infection control practices and beliefs of Minnesota dental hygienists and dental assistants. J Dent Hyg 1990;64:376381.

16 Nemutandani MS, Yengopal V, Rudolph MJ, Tsotsi NM: Occupational exposures among dental assistants in public health care facilities, Limpopo Province. SADJ 2007;62:348, 352-355.

17 Chen W, Gluud C: Vaccines for preventing hepatitis B in health-care workers. Cochrane Database Syst Rev 2005;4:CD000100.

18 Song KB, Choi KS, Lang WP, Jacobson JJ: Hepatitis $B$ prevalence and infection control among dental health care workers in a community in South Korea. J Public Health Dent 1999;59:39-43.

19 Noble MA, Mathias RG, Gibson GB, Epstein JB: Hepatitis B and HIV infections in dental professionals: effectiveness of infection control procedures. J Can Dent Assoc 1991;57: 55-58.

20 Nagao Y, Matsuoka H, Kawaguchi T, Ide T, Sata M: HBV and HCV infection in Japanese dental care workers. Int J Mol Med 2008;21: 791-799.

21 Al-Dwairi ZN: Infection control procedures in commercial dental laboratories in Jordan. J Dent Educ 2007;71:1223-1227.

22 Akeredolu PA, Sofola OO, Jokomba O: Assessment of knowledge and practice of crossinfection control among Nigerian dental technologists. Niger Postgrad Med J 2006; 13:167-171.

23 Utomi IL: Attitudes of Nigerian dentists towards hepatitis $B$ vaccination and use of barrier techniques. West Afr J Med 2005;24: 223-226.

24 King TB, Muzzin KB: A national survey of dental hygienists' infection control attitudes and practices. J Dent Hyg 2005;79:8.

25 Rudolph MJ, Ogunbodede EO: HIV infection and oral health care in South Africa. SADJ 1999;54:594-601. 